\title{
PENGARUH PERSEPSI MANAJER TENTANG KEBIJAKAN PERUSAHAAN, PERILAKU KEPEMIMPINAN DAN MOTIVASI KERJA TERHADAP PRODUKTIVITAS
}

\begin{abstract}
Mudjiardjo ${ }^{\bullet}$
Abstract: The objective of this research is to find out the effect of manager's perception to company policy, leadership behavior and work motivation on productivity. This research was conducted in Shipping Department of PT. Pertamina (Persero) Jakarta, on January to March 2008. The data were collected from 40 middle managers as unit analysis and selected by simple random sampling technique. The results of this research are as follow: (1). There is direct effect of the manager's perception to company policy on work motivation, (2). There is no direct effect of manager's perception to company policy on productivity, (3) There is direct effect of leadership behaviour on work motivation, (4) There is direct effect of leadhership behaviour on productivity, (5) There is direct effect of work motivation on productivity, (6) There is indirect effect of manager's perception to company policy through work motivation on productivity, and (7) There is indirect effect of leadhership behaviour through work motivation on productivity. Therefore to increase productivity can be carried out by improving manager's perception to company policy, improving leadhership behaviour and increasing work motivation.
\end{abstract}

Keywords: Perception, policy, leadership behavior, work motivation, and productivity.

\section{PENDAHULUAN}

Sejak tanggal 9 Oktober 2003 secara hukum, status Pertamina berubah dari Badan Usaha Milik Negara menjadi PT. Persero. Dengan sendirinya perubahan status tersebut juga berpengaruh pada sifat operasional, yang tadinya berdasarkan anggaran menjadi bersifat berorientasi pada keuntungan atau profit oriented. Bidang Perkapalan adalah salah satu unit operasi yang masih dipertahankan keberadaannya oleh Direksi, karena selain diharapkan dapat menjadi unit usaha strategis yang dapat berkembang, unit operasi ini mengemban tugas pokok di bidang pengangkutan bahan bakar minyak ke seluruh pulau di Indonesia. Dalam melaksanakan tugas pokok tersebut, bidang perkapalan menghadapi berbagai masalah, antara lain: (1) kebutuhan BBM dalam negeri dari tahun ke tahun mengalami peningkatan secara cepat, sehingga diperlukan kapalkapal tanker yang handal untuk mengangkutnya, karena apabila terjadi kelambatan penghantaran (supply), maka akan terjadi krisis persediaan BBM di depot-depot, yang dapat mengakibatkan terjadinya keresahan di masyarakat; (2) untuk memenuhi sarana angkutan BBM ke seluruh pulau di Indonesia, Bidang Perkapalan mengoperasikan sebanyak 164 unit kapal tanker dengan berbagai ukuran. Dari jumlah tersebut, kapal tanker hanya sebanyak 34 unit atau sekitar 20\% dari jumlah kebutuhan seluruhnya, sedangkan yang lainnya sebanyak 130 unit atau sekitar $80 \%$ dari jumlah kebutuhan seluruhnya menyewa dari pihak ketiga. Keadaan ini dapat menimbulkan kerawanan, karena selain harga sewa kapal sangat berfluktuasi mengikuti permintaan pasar, juga dapat menimbulkan kerawanan terhadap keamanan penghantaran (supply) BBM; (3) Masih terdapat faktor kelemahan perencanaan, misalnya: (a) Untuk kapal tanker dengan ukuran tertentu yang sesuai dengan perairan di Indonesia ----- terutama kapal tanker dengan ukuran 6000 DWT ----- sulit mendapatkannya di pasaran, karena jumlahnya

\footnotetext{
- Dosen Pasca Sarjana Strata-2 pada Sekolah Tinggi Manajemen IMNI - Jakarta
} 
relatif sedikit, sehingga harga sewanya relatif tinggi, di lain pihak untuk membangun kapal baru membutuhkan waktu lama; (b) Beberapa pelabuhan sarananya, kurang menunjang kelancaran pengoperasian kapal-kapal, misalnya alur pelayaran yang dangkal dan rambu-rambu pelayaran rusak karena kurang perawatan; (c) Ketersediaan muatan yang tidak menentu, seperti jumlah muatan yang belum mencukupi, sesuai dengan kapasitas kapal yang akan mengangkutnya.

Manajer menengah mempunyai peranan penting dalam kegiatan perusahaan untuk mengatasi masalah-masalah tersebut di atas, terutama masalah yang dihadapi oleh perusahaan dalam menjaga kehandalan kapal-kapal untuk mengangkut BBM. Mereka bertanggungjawab atas penyusunan program kerja, dan pengawasan pelaksanaan program kerja di bagian masing-masing. Di samping itu, manajer menengah juga memberikan supervisi kepada karyawan bawahannya untuk memperoleh cara terbaik dalam penggunaan sumberdaya perusahaan dalam upaya pencapaian tujuan organisasi perusahaan. Untuk meningkatkan efektivitas, manajer menengah melakukan evaluasi hasil kerja, yang dipakai sebagai masukan kepada pimpinan puncak untuk pedoman dalam pengambilan keputusan. Dalam upaya meningkatkan efisiensi, manajer menengah membantu para manajer umum (general manager) dan membina karyawan lainnya dengan sebaik mungkin dalam menggunakan enerji dan sumberdaya perusahaan. Untuk melaksanakan tugas dan tanggung jawab di bidang perkapalan, manajer menengah melakukan penyusunan program kerja, pembinaan karyawan, pengawasan pelaksanaan program kerja, evaluasai hasil kerja, penyusunan laporan tahunan serta pemanfaatan enerji dan sumberdaya perusahaan.

Produktivitas sangat berpengaruh terhadap pelaksanaan rencana kerja di bagian masing-masing yang merupakan satu kesatuan dalam pencapaian tujuan perusahaan. Ada beberapa indikator yang menunjukkan perlunya produktivitas ditingkatkan, antara lain: (1) Perencanaan program kerja perawatan kapal kurang akurat; (2) Pelaksanaan program kerja perbaikan kapal masih sering tidak sesuai dengan rencana; (3) Sistem pengadaan barang dan jasa terutama suku cadang untuk kapal masih sering tidak tepat waktu atau tidak sesuai dengan kebutuhan; (4) Masih sering terjadi krisis persediaan BBM di depot-depot tertentu yang disebabkan oleh kelambatan datangnya kapal menghantar BBM. Perencanaan perawatan kapal yang kurang akurat, pelaksanaan perbaikan yang berlarut-larut, dan pengadaan suku cadang yang tidak tepat waktu atau tidak sesuai dengan kebutuhan, dengan sendirinya akan menghambat kelancaran pengoperasian kapal dalam melaksanakan tugas pokoknya mengangkut BBM, sehingga akan mengganggu kelancaran distribusi BBM ke seluruh pulau di Indonesia. Atas dasar tuntutan adanya peningkatan produktivitas tersebut, penulis tertarik untuk melakukan penelitian tentang

pengaruh persepsi manajer tentang kebijakan perusahaan, perilaku kepemimpinan, dan motivasi kerja terhadap Produktivitas. Kajian dalam penulisan ini dibatasi pada kegiatan

para manajer menengah Bidang Perkapalan PT. Pertamina (Persero) dalam menjaga kehandalan kapal-kapal tanker pengangkut BBM. Sebagai dasar pemikiran, Bidang

Perkapalan mempunyai fungsi strategis dalam menunjang kelancaran distribusi BBM ke seluruh pulau di Indonesia. Organisasi Bidang Perkapalan PT. Pertamina (Persero) dipimpin oleh seorang Deputi Direktur, dibantu oleh Manajer Umum (General Manager), Manajer dan Asisten Manajer (sebagai manajer menengah), Pengawas serta seluruh karyawan pelaksana di Bidang Perkapalan. 
Produktivitas dipengaruhi antara lain oleh: (1) persepsi manajer tentang kebijakan perusahaan, yaitu tanggapan untuk mengerti atas semua peraturan perusahaan. Dengan mengerti dan memahami atas semua peraturan perusahaan, maka manajer menengah dalam menjalankan tugasnya akan selalu bertindak dan berperilaku sesuai dengan peraturan perusahaan serta menjadikannya pedoman dalam pengambilan keputusan; (2) perilaku Kepemimpinan, yaitu perilaku seorang pemimpin dalam mempengaruhi bawahannya agar mau bekerjasama untuk mewujudkan suatu tujuan tertentu. Untuk meningkatkan produktivitasnya, perilaku manajer menengah dalam mempengaruhi bawahannya sangat menentukan terciptanya kerjasama para bawahan dalam upaya mewujudkan tujuan perusahaan. Makin kuat pengaruh perilaku kepemimpinan manajer menengah terhadap bawahannya, makin tinggi produktivitas mereka; (3) motivasi kerja, adalah dorongan yang menyebabkan seseorang menjadi lebih bersemangat dalam bekerja sehingga akan meningkatkan produktivitasnya. Motivasi kerja ini merupakan salah satu faktor penting yang berpengaruh terhadap produktivitas. Makin kuat motivasi kerja manajer menengah akan menyebabkan mereka lebih giat bekerja sehingga produktivitas mereka akan meningkat.

\section{Persepsi Manajer Tentang Kebijakan Perusahaan}

Persepsi oleh John W. Newstrom (2007: 9) didefinisikan sebagai cara khusus tiap orang melihat, mengorganisasi dan menafsirkan sesuatu. Sedangkan Gibson dan kawan-kawan (2006: 99-100) menguraikan persepsi adalah proses di mana seorang individu memberi arti pada lingkungan. Ini meliputi pengorganisasian dan penafsiran atau penginterpretasian berbagai perangsang. Dengan perkataan lain, persepsi meliputi menerima perangsang, mengorganisasikan perangsang-perangsang tersebut dan menafsirkan atau menginterpretasikan perangsang yang sudah diorganisasikan tersebut mempengaruhi sikap dan perilaku.

Raymond J. Stone (2002: 848) menguraikan tentang kebijakan (policy) adalah suatu pernyataan umum yang menuntun para pengambil keputusan. Selanjutnya Pearce and Robinson dalam bukunya Strategic Management menguraikan tentang kebijakan adalah petunjuk yang direncanakan untuk menuntun pemikiran, keputusan dan tindakan para manajer dan bawahan mereka dalam melaksanakan suatu strategi perusahaan. Kebijakan membentuk pengawasan tidak langsung terhadap kebebasan bertindak dengan secara jelas dinyatakan bagaimana sesuatu dikerjakan sekarang. Dengan menetapkan keleluasaan, kebijakan dalam pengawasan pengaruh keputusan serta pemberdayaan para

karyawan melaksanakan aktivitas tanpa campur tangan langsung oleh manajemen puncak. Andrew J. Du Brin (2003: 129) menguraikan tentang kebijakan adalah petunjuk umum yang harus diikuti dalam membuat keputusan dan mengambil tindakan sebagaimana mereka rencanakan. Banyak kebijakan tertulis dan banyak kebijakan tidak tertulis. Kebijakan dirancang sesuai dengan rencana-rencana strategis, harus memberi

peluang untuk penafsiran oleh individu pimpinan. Salah satu peranan penting manajer adalah menafsirkan kebijakan bagi para karyawan Sedangkan Hunger dan Wheelen (2000) mendefinisikan kebijakan adalah suatu petunjuk secara luas untuk pengambilan keputusan yang berhubungan dengan rumusan strategi beserta pelaksanaannya. Perusahaan menggunakan kebijakan untuk memastikan bahwa para pegawai perusahaan membuat keputusan dan mengambil tindakan yang mendukung misi, tujuan dan strategi perusahaan. Persepsi manajer tentang kebijakan perusahaan tersebut sangat diperlukan, agar ada kesamaan pengertian, ada usaha untuk 
mengimplementasikan, menjadikan kebijakan tersebut sebagai petunjuk dalam mengambil keputusan serta sebagai pedoman bertindak dalam melaksanakan pekerjaan.

Dari beberapa konsep di atas, dapat disintesiskan bahwa kebijakan perusahaan adalah tanggapan untuk mengerti terhadap semua peraturan perusahaan, dengan indikator: Adanya kesamaan pengertian, adanya usaha untuk mengimplementasikan, sebagai petunjuk dalam mengambil keputusan serta sebagai pedoman bertindak dalam bekerja.

\section{Perilaku Kepemimpinan}

Dalam suatu organisasi diperlukan kepemimpinan seseorang, untuk mengatur tata tertib dan mengkoordinasi para anggota organisasi agar mau bekerja sama untuk mencapai suatu tujuan tertentu yang telah ditetapkan oleh organisasi itu. A. Shrode dan Voich, JR. (1974:358) menguraikan sebagai berikut: Kepemimpinan adalah suatu kualitas atau seperangkat ciri atau watak yang dimiliki oleh seseorang (seorang pemimpin) yang memungkinkan dia mempengaruhi perilaku orang lain untuk mencapai sasaran individu dan organisasi. Secara spesifik, kepemimpinan didefinisikan sebagai: "pengaruh antar pribadi, digunakan dalam situasi dan pengarahan melalui proses komunikasi, mengarah pada pencapaian suatu sasaran tertentu". Crawford, Kydd, and Riches (2005:2) juga memberikan definisi senada dengan menuliskan kepemimpinan mencakup cara mempengaruhi orang lain untuk mengajak mereka menuju ke suatu tujuan tertentu. Selanjutnya Nawawi (2003) menguraikan kepemimpinan dapat diartikan sebagai kemampuan/kecerdasan mendorong sejumlah orang (dua orang atau lebih) agar bekerjasama dalam melaksanakan kegiatan-kegiatan yang terarah pada tujuan bersama. Selanjutnya dalam buku ini diuraikan teori kepemimpinan McGregor sebagai berikut: Teori X berasumsi bahwa pada hakekatnya manusia itu memiliki perilaku malas, penakut, tidak mau bertanggung jawab.

Dalam hubungannya dengan kepemimpinan, maka Teori $X$ berpendapat bahwa gaya atau perilaku kepemimpinan otoriter merupakan yang paling efektif, karena manusia harus diperlakukan secara keras, pengawasan harus dilakukan secara ketat, karena tidak mau bertanggung jawab, cenderung senang melakukan pelanggaran, maka perlu diberi sangsi dan tindakan tegas. Sedangkan Teori $Y$ berasumsi bahwa pada dasarnya manusia itu memiliki perilaku bertanggung jawab, motivasi kerja, kreativitas, inisiatif dan mampu mengawasi pekerjaan dan dirinya sendiri. Teori $\mathrm{Y}$ sebagai kebalikan dari Teori $X$ berpendapt kepemimpinan yang efektif adalah yang demokratis. Kepemimpinan tersebut harus dijalankan dengan mengikutsertakan anggota organisasi dalam proses pengambilan keputusan, banyak melimpahkan wewenang, dan pengawasan yang longgar.

Dari beberapa konsep di atas, dapat disintesiskan bahwa perilaku kepemimpinan adalah perilaku seorang pemimpin dalam mempengaruhi bawahannya atau kelompok lain agar mau bekerjasama untuk mewujudkan suatu tujuan tertentu, dengan indikator: percaya kepada karyawan, mantap dalam membina karyawan, adil dan bijaksana, tegas dalam memberi sangsi serta demokratis dalam menjalankan tugas.

\section{Motivasi Kerja}

A. Usmara $(2006: 11,14)$ menguraikan bahwa motivasi adalah suatu kumpulan kekuatan tenaga yang berasal baik dari dalam maupun luar individu yang memulai sikap dan menetapkan bentuk, arah, serta intensitasnya. Organisasi benar-benar memerlukan para karyawan yang termotivasi untuk menjadi pekerja yang super 
produktif. Dari buku Essentials of Management oleh Andrew J. Du Brin (2003) diuraikan bahwa istilah motivasi menunjuk pada dua gagasan atau ide yang berbeda tetapi saling berhubungan. Dari sisi individual, motivasi adalah suatu keadaan internal yang mengarahkan pada pencapaian tujuan. Motivasi pribadi mempengaruhi inisiatif, arah, intensitas dan ketekunan berusaha. Seorang pekerja yang termotivasi akan memulai, memfokuskan usaha pada arah yang benar, bekerja dengan intensitas, dan berusaha terus-menerus. Selanjutnya Gibson, dkk (2006:132) menguraikan tentang motivasi adalah kekuatan bertindak pada seorang karyawan yang memprakarsai dan mengarahkan perilaku. Yudith R. Gordon (2002:102) menuliskan tentang motivasi sebagai berikut: Motivasi berhubungan dengan cara mendapatkan hasil yang diinginkan dari para karyawan yang membantu pencapaian tujuan. Chuck Williams (2003:606) mendefinisikan motivasi adalah kumpulan kekuatan yang memprakarsai, mengarahkan, dan membuat orang secara berkelanjutan berupaya mencapai suatu tujuan. Uraian ini diperkuat oleh Bateman dan Snell (2004) dalam bukunya Management yang menyatakan bahwa motivasi menunjuk pada kekuatan-kekuatan yang menguatkan, mengarahkan dan mendukung usaha-usaha seseorang. Orang yang sangat termotivasi akan bekerja keras untuk pencapaian tujuan. Dengan kemampuan yang memadai dan memahami akan pekerjaan, orang yang demikian akan menjadi sangat produktif.

Dari beberapa konsep di atas, dapat disintesiskan bahwa motivasi kerja adalah dorongan yang menyebabkan seseorang menjadi lebih bersemangat dalam bekerja, sehingga akan meningkatkan produktivitasnya, dengan indikator: adanya semangat kerja, lebih tekun dalam bekerja, lebih kreatif, lebih berinisiatif dan mempunyai tujuan yang jelas dalam bekerja.

\section{Produktivitas}

L. David Korb (1964) menuliskan pengertian produktivitas adalah sebagai kesediaan para pekerja untuk mengarahkan tenaga dalam menghasilkan barang dan jasa yang menjadi tujuan usaha tertentu. Para pengawas dalam perusahaan dapat meningkatkan produktivitas dengan menempuh jalan sebagai berikut: (a) menggunakan tenaga dan upaya pegawai dengan lebih baik, (b) mengorganisir tugas pekerjaan dan pembagiannya sehingga mempermudah pencapaian hasil, (c) melatih pegawai untuk dapat bekerja secara efisien, (d) berusaha untuk memperoleh pengertian tentang pegawai, baik sebagai individu maupun sebagai anggota kelompok, (e) menciptakan suatu

semangat kerjasama kelompok yang dapat merangsang setiap pegawai untuk bekerja lebih baik, (f) membina dan meyakinkan pegawai ke arah cita-cita untuk melakukan pekerjaan yang bermanfaat, $(\mathrm{g})$ memberikan penghargaan yang layak atas gagasan yang bermutu dan pelaksanaan tugas yang superior, (h) memberikan kesempatan penuh kepada pegawai untuk memperlihatkan kompetensinya.

Sedangkan Russel dan Taylor III (1998: 99-100) menguraikan tentang produktivitas adalah suatu ukuran dari keefektifan suatu perusahaan dalam mengubah masukan menjadi keluaran. Robbins dan De Cenzo (2003) dalam buku Fundamentals of Management menuliskan produktivitas diartikan sebagai seluruh keluaran dari barang dan jasa yang diproduksi dibagi dengan masukan yang diperlukan untuk menghasilkan keluaran tersebut. Organisasi yang efektif akan memaksimalkan produktivitas dengan secara berhasil memadukan orang-orang ke dalam seluruh sistem operasi. 
Dari beberapa konsep di atas, dapat disintesiskan bahwa Produktivitas adalah efektivitas dan efisiensi manajer menengah dalam melaksanakan tugas-tugas yang dibebankan kepadanya, dengan indikator: efektivitas dalam penyusunan program kerja, pembinaan karyawan, pengawasan pelaksanaan program kerja, evaluasi hasil kerja, penyusunan laporan tahunan, dan efisiensi pemanfaatan sumberdaya perusahaan.

\section{METODE}

Metode yang digunakan dalam penelitian ini adalah metode survei dengan menerapkan kajian hubungan kausal. Penelitian dilaksanakan di kantor Bidang Perkapalan PT. Pertamina (Persero), beralamat di Jl. Jos Sudarso No. 32-34 Tanjung Priok Jakarta Utara, Populasi untuk penelitian ini adalah para manajer menengah yang terdiri dari para manajer dan asisten manajer di Bidang Perkapalan PT. Pertamina (Persero). Populasi terjangkau sebanyak 56 orang sekaligus sebagai kerangka sampel. Jumlah sampel ditentukan sebanyak 40 orang dengan teknik simple random sampling, karena populasinya homogen.

\section{HASIL DAN PEMBAHASAN}

Berdasarkan hasil analisis dan pengujian hipotesis menunjukkan bahwa kelima hipotesis yang diajukan dalam penelitian ini ada satu hipotesis yang tidak terbukti, yaitu persepsi manajer tentang kebijakan perusahaan ternyata tidak berpengaruh langsung terhadap produktivitas. Hal ini mengandung makna bahwa secara umum, dilingkungan Bidang Perkapalan PT. PERTAMINA (Persero) terdapat pengaruh langsung: (1) persepsi

manajer tentang kebijakan perusahaan terhadap motivasi kerja; (2) perilaku kepemimpinan terhadap motivasi kerja; (3) perilaku Kepemimpinan terhadap produktivitas; (4) motivasi kerja terhadap produktivitas; (5) persepsi manajer tentang kebijakan perusahaan melalui motivasi kerja secara tidak langsung berpengaruh terhadap produktivitas. Secara rinci, pembahasan hasil analisis dan pengujian hipotesis penelitian diuraikan sebagai berikut:

Pertama, berhubungan dengan hasil analisis hubungan antara persepsi manajer tentang kebijakan perusahaan dengan motivasi kerja. Terdapat hubungan yang positif antara kedua variabel ini mengandung makna bahwa makin positif persepsi manajer tentang kebijakan perusahaan, makin kuat motivasi kerja para manajer menengah.

Dengan derajat koefisien hubungan sebesar 0,575 dan uji signifikasi didapatkan hasil bahwa koefisien hubungan sangat signifikan, maka dapat dikatakan bahwa varians motivasi kerja dapat dijelaskan oleh varians persepsi manajer tentang kebijakan perusahaan. Setelah dilakukan perhitungan koefisien jalur antara persepsi manajer tentang kebijakan perusahaan dengan motivasi kerja, diperoleh hasil nilai koefisien jalur sebesar 0,421. Karena dalam penelitian ini ditentukan batas nilai signifikansi sebesar 0,05, maka apabila nilai koefisien jalur lebih kecil dari 0,05, dapat dianggap tidak bermakna dan dapat dianggap tidak ada pengaruh. Tetapi ternyata nilai koefisien jalur hasil perhitungan sebesar 0,421 lebih besar dari 0,05, maka koefisien jalur tersebut sangat signifikan dan dapat dikatakan bahwa terdapat pengaruh yang sangat signifikan antara persepsi manajer tentang kebijakan perusahaan terhadap motivasi kerja. Berdasarkan pembuktian secara empirik ini, maka dapat dikatakan bahwa temuan penelitian ini menunjukkan bahwa persepsi manajer tentang kebijakan perusahaan, salah satu 
variabel penentu yang sangat penting dan berpengaruh langsung terhadap variabel motivasi kerja. $\rho_{42}=0,330$, dan $\rho_{43}=0,351$.

Untuk menjelaskan bagaimana persepsi manajer tentang kebijakan perusahaan bepengaruh kepada motivasi kerja, dipakai analog dari Equity Theory yang ditulis oleh Chuck Williams (2003:616) yang mengatakan bahwa orang akan termotivasi pada pekerjaan ketika mereka mempunyai persepsi bahwa mereka diperlakukan secara wajar dan adil. Secara khusus, equity theory menekankan pentingnya persepsi. Analog dengan teori ini, maka manajer menengah akan termotivasi untuk bekerja keras, apabila mempunyai persepsi yang benar terhadap kebijakan perusahaan. Untuk itu para manajer menengah hendaknya mampu menafsirkan secara benar dan mempunyai tanggapan yang positif atas kebijakan perusahaan, agar dapat meningkatkan motivasi kerja mereka dan karyawan bawahannya. Dari uraian teori di atas dan berdasarkan pembuktian secara empirik yang dilaksanakan dalam penelitian ini, terbukti bahwa persepsi manajer tentang kebijakan perusahaan berpengaruh langsung terhadap motivasi kerja.

Kedua, berhubungan dengan hasil analisis hubungan antara persepsi manajer tentang kebijakan perusahaan dengan produktivitas. Terdapat hubungan yang positif antara kedua variabel ini, mengandung makna bahwa makin positif persepsi manajer tentang kebijakan perusahaan, makin tinggi pula produktivitas. Dengan derajat koefisien hubungan sebesar 0,325 dan uji signifikansi didapatkan hasil bahwa koefisien hubungan signifikan, maka dapat dikatakan bahwa varians Produktivitas dapat dijelaskan oleh varians persepsi manajer tentang kebijakan perusahaan. Setelah dilakukan perhitungan koefisien jalur antara persepsi manajer tentang kebijakan perusahaan dengan produktivitas, diperoleh hasil nilai koefisien jalur sebesar $-0,036$. Karena dalam penelitian ini ditentukan batas nilai signifikansi sebesar 0,05, maka apabila nilai koefisien jalur lebih kecil dari 0,05, dapat dianggap tidak bermakna dan dapat dianggap tidak ada pengaruh. Tetapi ternyata nilai koefisien jalur hasil perhitungan sebesar -0,036 lebih kecil dari 0,05, maka koefisien jalur tersebut tidak bermakna dan dapat dikatakan tidak terdapat pengaruh langsung antara persepsi manajer tentang kebijakan perusahaan terhadap produktivitas. Tetapi melalui variabel motivasi kerja, persepsi manajer terhadap kebijakan perusahaan mempunyai pengaruh tidak langsung sebesar 0,148 terhadap produktivitas. Berdasarkan pembuktian secara empirik, maka temuan penelitian ini menunjukkan

bahwa persepsi manajer tentang kebijakan perusahaan tidak berpengaruh langsung terhadap produktivitas, tetapi melalui motivasi kerja variabel persepsi manajer tentang kebijakan perusahaan berpengaruh tidak langsung terhadap produktivitas. Berdasarkan teori A.B. (Rami) Shani dan James B.Lau (2005:10), yang menguraikan bahwa di dalam tiap organisasi, orang-orang didalam departemen yang berbeda (sebagai contoh: penjualan, engineering, pemasaran, produksi) akan mempunyai persepsi terhadap suatu topik diskusi secara berbeda, maka wajar apabila tiap karyawan mempunyai persepsi yang berbeda terhadap suatu kebijakan perusahaan. Teori Andrew. J. Du Brin (2003:129) menyatakan bahwa salah satu peranan penting para manajer adalah menafsirkan kebijakan bagi para karyawan. Maka menjadi tugas para manajer menengah di Bidang Perkapalan PT. Pertamina (Persero) untuk menafsirkan kebijakan-kebijakan perusahaan bagi dirinya sendiri dan bagi para karyawan bawahannya, sehingga motivasi kerja mereka menjadi lebih kuat, dan pada akhirnya akan berpengaruh terhadap peningkatan Produktivitas. 
Ketiga, berhubungan dengan hasil analisis hubungan antara perilaku kepemimpinan dengan motivasi kerja. Terdapat hubungan yang positif antara kedua variabel ini, mengandung makna bahwa makin besar pengaruh perilaku kepemimpinan para manajer menengah, makin kuat motivasi kerja mereka. Dengan derajat koefisien hubungan sebesar 0,533 dan uji signifikansi di dapatkan hasil bahwa koefisien hubungan sangat signifikan, maka dapat dikatakan bahwa varians motivasi kerja dapat dijelaskan oleh varians perilaku kepemimpinan. Setelah dilakukan perhitungan koefisien jalur antara perilaku kepemimpinan dengan motivasi kerja, diperoleh hasil nilai koefisien jalur sebesar 0.346. Karena dalam penelitian ini ditetapkan batas nilai signifikansi sebesar 0,05, maka apabila nilai koefisien jalur lebih kecil dari 0,05, dapat dianggap tidak bermakna dan dapat dianggap tidak ada pengaruh. Tetapi ternyata nilai koefisien jalur hasil perhitungan sebesar 0,346 lebih besar dari 0,05, maka koefisien jalur tersebut signifikan dan dapat dikatakan bahwa terdapat pengaruh yang signifikan antara perilaku kepemimpinan dengan motivasi kerja. Berdasarkan pembuktian secara empirik ini, maka temuan penelitian ini menujukkan bahwa perilaku kepemimpinan merupakan salah satu variabel penentu yang sangat penting dan berpengaruh langsung terhadap motivasi kerja. Uraian teori Bateman dan Snell (2004: 398) menyatakan bahwa: "menjadi motivator yang efektif, para manajer harus mengetahui perilaku apa yang mereka inginkan untuk memotivasi orang agar menunjukkan keinginan mereka tersebut." Selanjutnya diuraikan bahwa orang yang sangat termotivasi akan bekerja keras untuk pencapaian tujuan. Berdasarkan teori di atas dan pembuktian secara empirik yang dilaksanakan dalam penelitian ini, terbukti bahwa Perilaku Kepemimpinan berpengaruh langsung terhadap Motivasi Kerja.

Keempat, berdasarkan hasil analisis hubungan antara perilaku kepemimpinan dengan produktivitas, terdapat hubungan yang positif antara kedua variabel ini, mengandung makna bahwa makin besar pengaruh perilaku kepemimpinan para manajer menengah, makin tinggi produktivitas mereka. Dengan derajat koefisien hubungan sebesar 0,517 dan uji signifikansi didapatkan hasil bahwa koefisien hubungan sangat signifikan, maka dapat dikatakan bahwa varians produktivitas dapat dijelaskan oleh Varians perilaku kepemimpinan. Setelah dilakukan perhitungan koefisien jalur antara kedua variabel ini, diperoleh hasil koefisien jalur sebesar 0,330. Karena dalam penelitian

ini ditentukan batas nilai signifikansi sebesar 0,05, maka apabila nilai koefisien jalur lebih kecil dari 0,05, maka dapat dianggap tidak bermakna dan dianggap tidak ada pengaruh. Tetapi ternyata koefisien jalur hasil perhitungan sebesar 0,330 lebih besar dari 0,05, maka koefisien jalur tersebut signifikan dan dapat dikatakan bahwa terdapat pengaruh yang signifikan antara perilaku kepemimpinan terhadap produktivitas. Melalui variabel motivasi kerja, perilaku kepemimpinan juga mempunyai pengaruh tidak langsung terhadap produktivitas sebesar 0,122. Berdasarkan pembuktian secara empirik ini, maka dapat dikatakan bahwa temuan penelitian ini menunjukkan perilaku kepemimpinan merupakan salah satu variabel penentu yang sangat penting karena berpengaruh langsung dan tidak langsung terhadap produktivitas. Perilaku pemimpin yang mempengaruhi bawahan ditandai antara lain percaya kepada karyawan, mantap dalam membina karyawan, adil dan bijaksana, tegas dalam memberi sangsi, dan demokratis dalam menjalankan tugas. Hal ini terangkum dalam Path-Goal Leadership Theory yang menyatakan bahwa pekerjaan pemimpin adalah memanfaatkan susunan atau struktur dalam organisasi, menghargai dan mendukung menciptakan suatu lingkungan kerja yang membantu karyawan mencapai tujuan organisasi (John 
Newstrom 2007:170). Dari uraian teori tersebut di atas dan berdasarkan pembuktian secara empirik yang dilaksanakan dalam penelitian ini, terbukti bahwa perilaku kepemimpinan berpengaruh langsung dan tidak langsung terhadap produktivitas.

Kelima, berhubungan dengan hasil analisis hubungan antara motivasi kerja dengan produktivitas, terdapat hubungan yang positif antara kedua variabel tersebut, mengandung makna bahwa makin kuat motivasi kerja, makin tinggi produktivitas manajer menengah. Dengan derajat koefisien korelasi sebesar 0,527 dan uji signifikansi didapatkan hasil bahwa koefisien korelasi sangat signifikan, maka dapat dikatakan bahwa varians produktivitas dapat dijelaskan oleh varians motivasi kerja. Setelah dilakukan perhitungan koefisien jalur antara motivasi kerja dengan produktivitas, diperoleh hasil nilai koefisien jalur sebesar 0,351. Karena dalam penelitian ini ditetapkan batas nilai signifikansi sebesar 0,05, maka apabila nilai koefiisien jalur lebih kecil dari 0,05, maka dapat dianggap tidak bermakna dan dapat dianggap tidak ada pengaruh. Tetapi ternyata nilai koefisien jalur hasil perhitungan sebesar 0,351 lebih besar dari 0,05, maka koefisien jalur tersebut signifikan, dan dapat dikatakan bahwa terdapat pengaruh yang signifikan antara motivasi kerja terhadap produktivitas. Berdasarkan pembuktian secara empirik ini, maka temuan penelitian ini menunjukkan bahwa motivasi kerja merupakan salah satu variabel penentu yang sangat penting dan berpengaruh langsung terhadap roduktivitas. Hal ini didukung oleh teori Bateman dan Snell (2004: 398) yang menyatakan bahwa : "orang yang termotivasi tinggi akan bekerja keras untuk pencapaian tujuan." Dengan kemampuan yang memadai dan memahami akan pekerjaan, orang yang demikian akan menjadi sangat produktif. Tentu saja, perusahaan menginginkan orang akan melaksanakan, yaitu para karyawan akan bekerja keras untuk mencapai keluaran yang tinggi (produktivitas tinggi) dan kualitas tinggi". Dari uraian teori di atas dan pembuktian secara empirik yang dilaksanakan dalam penelitian ini terbukti bahwa Motivasi Kerja berpengaruh langsung terhadap Produktivitas.

\section{PENUTUP}

Kesimpulan. Berdasarkan analisis yang telah dilaksanakan pada BAB IV, temuan dalam penelitian ini adalah sebagai berikut: (1) Terdapat pengaruh langsung persepsi manajer tentang kebijakan perusahaan $\left(X_{1}\right)$ terhadap motivasi kerja $\left(X_{3}\right)$ dengan nilai koefisien jalur 0,421. (2) Tidak terdapat pengaruh langsung persepsi manajer tentang kebijakan perusahaan $\left(X_{1}\right)$ terhadap produktivitas $\left(X_{4}\right)$. (3) Terdapat pengaruh langsung perilaku kepemimpinan $\left(X_{2}\right)$ terhadap motivasi kerja $\left(X_{3}\right)$ dengan nilai koefisien jalur 0,346 . (4) Terdapat pengaruh langsung perilaku kepemimpinan $\left(X_{2}\right)$ terhadap produktivitas $\left(X_{4}\right)$ dengan nilai koefisien jalur 0,330 . (5) Terdapat pengaruh langsung motivasi kerja $\left(X_{3}\right)$ terhadap produktivitas (X4) dengan nilai koefisien jalur 0,351. (6) Terdapat pengaruh tidak langsung persepsi manajer tentang kebijakan perusahaan $\left(X_{1}\right)$ melalui motivasi kerja $\left(X_{3}\right)$ terhadap produktivitas $\left(X_{4}\right)$ terhadap produktivitas $\left(X_{4}\right)$ dengan nilai koefisien jalur 0,148. (7) Terdapat pengaruh tidak langsung perilaku kepemimpinan $\left(\mathrm{X}_{2}\right)$ melalui motivasi kerja $\left(X_{3}\right)$ terhadap produktivitas $\left(X_{4}\right)$ dengan nilai koefisien jalur 0,122.

Saran. Berdasarkan temuan dan kesimpulan hasil penelitian yang telah diuraikan sebelumnya, maka dalam upaya peningkatan produktivitas karyawan, khususnya manajer menengah Bidang Perkapalan PT. Pertamina (Persero), saran-saran yang diberikan dalam disertasi ini adalah sebagai berikut: (1) Pimpinan Bidang Perkapalan PT. Pertamina (Persero) diharapkan dapat melakukan usaha-usaha untuk mendorong 
perbaikan persepsi karyawan, khususnya para manajer menengah tentang kebijakan perusahaan, perbaikan perilaku kepemimpinan dan peningkatan motivasi kerja. Hal ini perlu dilakukan, karena dampaknya dapat meningkatkan produktivitas. (2) Kepada para karyawan, khususnya para manajer menengah Bidang Perkapalan PT. Pertamina (Persero) agar selalu berusaha meningkatkan produktivitas mereka agar dapat menunjang perusahaan untuk menghasilkan keuntungan bagi Negara sesuai dengan tuntutan undang-undang dan Peraturan Pemerintah yang berlaku. 


\section{DAFTAR RUJUKAN}

Bateman, Thomas S, Scott A. Snell. Management The New Competitive Landscape. 6th Edition. New York: Mc Graw - Hill/Irwin, 2004.

Crawford, Megan, Heley Kydd, Colin Riches. Kepemimpinan dan Kerjasama Tim di Dalam Manajemen Kependidikan. Penerjemah: Erick Dibyo Wibowo. Jakarta: Grasindo, 2005.

Du Brin, Andrew J. Essentials of Management. Sixth Edition. USA: Thomson SouthWestern, 2003.

Gibson, James L, John M. Ivancevich, James H. Donnelly, Jr. Robert Konopaske; Organizations Behavior, Structure, Processes. Twelfth Edition. USA: Mc. Graw-Hill, 2006.

Gordon, Yudith. R. Organizational Behavior, A Diagnostics Approach. Seventh Edition. New Jersey: Prentice Hall, 2002.

Hunger, J. David, Thomas L. Wheelen. Strategic Management. 7th Edition. USA: Prentice Hall, 2000.

Korb, L. David. American Management Association; Kepemimpinan Dalam Perusahaan. Diterjemahkan oleh Slamet Wijadi. Jakarta: Bhratara, 1964.

Nawawi, Hadari. Kepemimpinan Mengefektifkan Organisasi. Yogyakarta: Gadjah Mada University Press, 2003.

Newstrom, John W. Organizational Behavior, Human Behavior at Work. Twelfth Edition. USA: Mc. Graw-Hill, 2007.

Robbins, Stephen P., David De Cenzo. Fundamentals of Management, Essential Concepts and Applications. Fourth Edition. New Jersey: Pearson Prentice Hall, 2003.

Russel, Roberta S. dan Bernard W. Taylor III. Operations Management Focusing on Quality, Competitiveness. Second Edition. New Jersey: Prentice Hall, 1998.

Shrode, William A. dan Dan Voich, JR. Organization and Managemen : Basic Systems Concepts. Malaysia: Irwin Book Company, 1974.

Stone, Raymond J. Human Resources Management. Fourth Edition. Australia: John Wiley \& Sons, 2002.

Usmara, A. Motivasi Kerja: Proses, Teori dan Praktik. Yogyakarta: Amara Books, 2006.

Williams, Chuck. Management. 2nd Edition. USA: Thomson South - Western, 2003. 